\title{
Value Engineering Implementation on Construction Project of Suzuya Plaza, Tanjung Morawa
}

\author{
Syahrizal $^{1}$, Fatimah Almadinah ${ }^{2}$, Rahmi Karolina ${ }^{1}$, M. Agung P Handana ${ }^{1}$ \\ \{*rizal_ar@ymail.com \} \\ ${ }^{1}$ Lecturer of Department of Civil Engineering, Universitas Sumatera Utara, Medan, Indonesia \\ ${ }^{2}$ Student of Department of Civil Engineering, Universitas Sumatera Utara, Medan, Indonesia
}

\begin{abstract}
A construction project can't be separated from costs, time, human resources and natural resources. Every project implementer always wants to be able to complete a construction project at the most economical cost possible. But this must be done with techniques that have been tested for success. The cost saving technique used must still pay attention to the quality, reliability and usefulness of a building that is being worked on. One of the saving techniques that have been tested for success is value engineering. In an alternative selection, an analysis of the advantages and disadvantages of the ideas obtained in the creative stage is carried out. The assessment factors carried out on the alternatives to be chosen are initial costs, aesthetics, implementation time, level of implementation, durability, level of comfort, and level of environmental friendliness. The alternative chosen is an alternative that has the highest assessment results in the analysis stage, then calculating the costs required in the next stage. Work items that have the highest costs are on roof work with a total initial cost of Rp. 434,560,000.00. After value engineering carried out, it is obtained that the selected alternative is using $0.35 \mathrm{~mm}$ zincalume roof with a savings of Rp. 183,123,584 of the initial cost. The savings is around $3.6 \%$ of the total cost of the analyzed structure. Thus, one of the objectives of value engineering application which is cost savings is achieved.
\end{abstract}

Keywords: Value engineering, cost savings, construction project

\section{Introduction}

A construction project can't be separated from costs, time, human resources and natural resources. Every project implementer always want to be able to complete a construction project at the most economical cost possible. But this must be done with techniques that have been tested for success. The cost saving technique used must still pay attention to the quality, reliability and usefulness of a building that is being worked on [1]. If it is done without proper analysis, it will cause something harmful to project implementers and building users. Therefore, the implementer must do a good management in the construction project.

P In a construction project, an evaluation can still be carried out which aims to get a more optimal and maximum results while still paying attention to the quality and performance function of a building that in accordance with the plan, which is by doing Value Engineering [2]. Value engineering is a proven management technique that uses a systematic approach system by a group (team) that is directed to analyze the function of an item or system, product, facility, project, or service in order to achieve the required function with the most minimum 
total cost, being consistent with the provisions for appearance, reliability, quality and maintenance of items or systems, products, facilities, projects or services. [3].

The implementation of value engineering is expected to know the most optimal costs that aim to get savings but still pay attention to the quality, reliability and main function of a building [4]. So that construction service providers can still compete better in the world of construction.

The purposes of this research are to find out what work that can be optimized, and to find out how much savings are obtained.

\section{Methodology}

The methods used in this study are the stages of value engineering. These stages include: Information stage; Creative stage; Analysis stage; Development stage; Presentation stage.

\subsection{Information Stage}

Collecting information thoroughly about a project that will be studied. Perform a pareto analysis to get the highest cost of work items, then proceed by making a breakdown cost table. After that, a diagram of Functional Analysis System Technique (FAST) is drawn and performs a function analysis on high cost work items that have a value of cost/worth $>1$.

\subsection{Creative Stage}

A stage to bring up as many creative ideas as possible while still referring to the desired functions that have been determined and evaluated. Can be started by describing a general or conventional things up to the methods that follow the developments that occur.

\subsection{Analysis Stage}

Analyzing the advantages and disadvantages by providing an assessment of creative ideas obtained. Factors assessed are the initial costs, aesthetics, implementation time, level of implementation, level of durability, level of comfort, and friendliness of the environment [5]. The alternative chosen is the one that has the highest assessment results.

\subsection{Development Stage}

Calculating the costs needed to replace the initial design with the alternatives that have been selected at the analysis stage [6]. An alternative that resulting cost savings will be proposed at a later stage.

\subsection{Presentation Stage}

Presenting selected alternative results in the form of graphs resulting from the analysis of the advantages and disadvantages to be easily understood.

\section{Result and Discussion}

\subsection{Information Stage}

The information of works items can be seen at the tabel below. 
Table 1. Identification of High Costs on Work Items

\begin{tabular}{|c|c|c|c|c|}
\hline No & Work Items & Costs & $\begin{array}{c}\text { Costs } \\
(\%)\end{array}$ & $\begin{array}{c}\text { Cumu-Lative } \\
\text { Percentage }\end{array}$ \\
\hline 1 & $2^{\text {nd }}$ FLOOR & 1.830 .169 .297 & 28,64 & 28,64 \\
\hline 2 & $3^{\text {rd }}$ FLOOR & 1.639 .828 .056 & 25,66 & 54,31 \\
\hline 3 & $\begin{array}{l}\text { GROUND } \\
\text { FLOOR/1 }\end{array}$ & 614.201 .801 & 9,61 & 63,92 \\
\hline 4 & ROOF & $449.560 .000,00$ & 7,04 & 70,96 \\
\hline 5 & COLUMN & $309.894 .000,00$ & 4,85 & 75,81 \\
\hline 6 & RAFTER & $305.088 .120,00$ & 4,77 & 80,58 \\
\hline 7 & GORDING & $254.160 .930,00$ & 3,98 & 84,56 \\
\hline 8 & $\begin{array}{l}3^{\text {rd }} \text { FLOOR } \\
\text { MASONRY }\end{array}$ & 207.427.248 & 3,25 & 87,80 \\
\hline 9 & $\begin{array}{l}2^{\text {nd }} \text { FLOOR } \\
\text { MASONRY }\end{array}$ & 196.633 .276 & 3,08 & 90,88 \\
\hline $\begin{array}{l}10 \\
11\end{array}$ & $\begin{array}{l}\text { BEAM } \\
\text { PLATE }\end{array}$ & $\begin{array}{c}154.447 .620,00 \\
96.770 .100,00\end{array}$ & $\begin{array}{l}2,42 \\
1,51\end{array}$ & $\begin{array}{l}93,30 \\
94,81\end{array}$ \\
\hline 12 & $\begin{array}{l}\text { ELEVATOR } \\
\text { WORK }\end{array}$ & 69.149 .518 & 1,08 & 95,90 \\
\hline 13 & $\begin{array}{c}\text { ENGINE ROOM } \\
\text { OF ELEVATOR } \\
\text { FLOOR }\end{array}$ & 64.516 .691 & 1,01 & 96,90 \\
\hline 14 & $\begin{array}{l}\text { PAINT } \\
\text { BOTTOM }\end{array}$ & $46.359 .756,00$ & 0,73 & 97,63 \\
\hline 15 & $\begin{array}{l}\text { STRUCTURE } \\
\text { WORK }\end{array}$ & $42.305 .103,25$ & 0,66 & 98,29 \\
\hline 16 & $\begin{array}{l}\text { DECK FLOOR OF } \\
\text { ENGINE ROOM }\end{array}$ & 41.356 .282 & 0,65 & 98,94 \\
\hline 17 & $\begin{array}{l}\text { ANCHORS, } \\
\text { BOLTS }\end{array}$ & $34.504 .000,00$ & 0,54 & 99,48 \\
\hline 18 & CLADDING & $22.999 .870,00$ & 0,36 & 99,84 \\
\hline 19 & $\begin{array}{l}\text { BRACING, } \\
\text { TRACKSTANG }\end{array}$ & $10.236 .000,00$ & 0,16 & 100,00 \\
\hline & Sum & 6.389 .607 .668 & 100 & \\
\hline
\end{tabular}

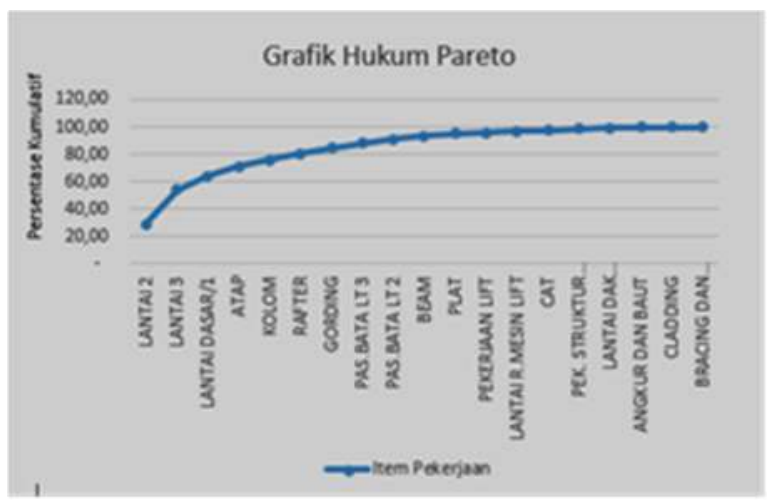

Fig.1. Pareto's Law

The distribution law of Pareto states that $80 \%$ of the total costs incurred in $20 \%$ of work items will be analyzed later. From the graph above, it can be stated that work items that can be applied in the implementation of value engineering is on the 2 nd floor, 3rd floor, ground floor, roof, column, and rafter.

Then detailing the costs that will be further analyzed which is part of the work items that meet Pareto analysis (Table 2). 
Table 2. Breakdown cost

\begin{tabular}{|c|c|c|}
\hline No. & Work Items & Costs \\
\hline 1 & Double plate tin roof (galvalum roof + insulation + wavy roof) & $434,560,000$ \\
\hline 2 & U39 Concrete iron ( $3^{\text {rd }}$ floor beam) & $399,847,520$ \\
\hline 3 & U39 Concrete iron ( $2^{\text {nd }}$ floor beam) & $372,332,290$ \\
\hline 4 & Floordeck Formwork $\mathrm{t}=0,75$ TCT $(0,70$ BMT $)$ ex. Cordeck ( $2^{\text {nd }}$ floor plate $)$ & $286,727,350$ \\
\hline 5 & Floordeck Formwork $\mathrm{t}=0,75$ TCT $(0,70$ BMT $)$ ex. Cordeck ( $3^{\text {rd }}$ floor plate $)$ & $280,525,700$ \\
\hline 6 & Formwork ( $3^{\text {rd }}$ floor beam) & $279,511,717$ \\
\hline 7 & Formwork ( $2^{\text {nd }}$ floor beam) & $269,618,705$ \\
\hline 8 & CNP $150 \times 50 \times 20 \times 3.2$ & $254,160,930$ \\
\hline 9 & K250 Concrete ( $2^{\text {nd }}$ floor plate $)$ & $250,981,500$ \\
\hline 10 & K250 Concrete ( $3^{\text {rd }}$ floor plate) & $245,553,000$ \\
\hline 11 & WF $400 \times 200 \times 8 \times 13$ & $223,938,000$ \\
\hline 12 & K250 Concrete ( $3^{\text {rd }}$ floor beam) & $218,241,975$ \\
\hline 13 & K250 Concrete ( $2^{\text {nd }}$ floor beam $)$ & $209,392,785$ \\
\hline 14 & WF $200 \times 100 \times 5.5 \times 8$ & $150,842,340$ \\
\hline 15 & U39 Concrete iron ( $1^{\text {st }}$ floor column) & $148,989,742$ \\
\hline 16 & WF $450 \times 200 \times 9 \times 14$ & $116,371,200$ \\
\hline 17 & U39 Concrete iron ( $2^{\text {nd }}$ floor column $)$ & $107,099,635$ \\
\hline 18 & WF $350 \times 175 \times 7 \times 11$ & $104,427,840$ \\
\hline 19 & Hebel Couple ( $3^{\text {rd }}$ floor) & $98,028,000$ \\
\hline 20 & U39 Concrete iron ( $1^{\text {st }}$ floor sloof) & $96,782,519$ \\
\hline 21 & Stucco + Acian ( $3^{\text {rd }}$ floor $)$ & $96,067,440$ \\
\hline 22 & Stucco + Acian ( $2^{\text {nd }}$ floor $)$ & $88,878,720$ \\
\hline 23 & Wiremesh M5 & $86,980,100$ \\
\hline 24 & Wiremesh M5 & $86,980,100$ \\
\hline 25 & Wiremesh M7 & $86,442,720$ \\
\hline \multirow[t]{2}{*}{26} & WF $450 \times 200 \times 9 \times 14$ & $85,956,000$ \\
\hline & Sum & 5.079 .237 .828 \\
\hline
\end{tabular}

Figure of FAST diagram on the reviewed work items

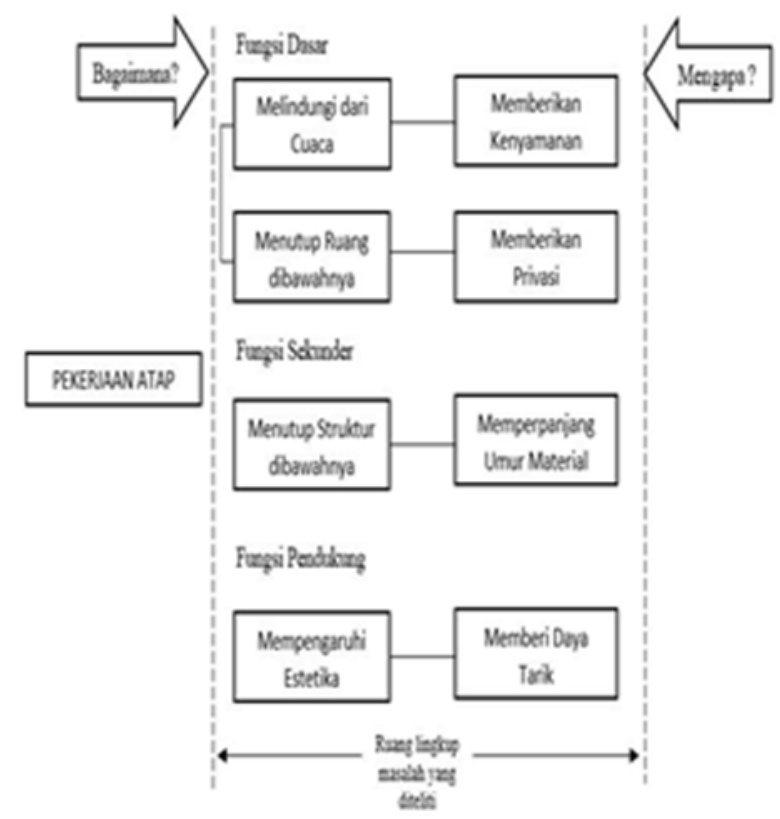

Fig.2. FAST Diagram of roof work 


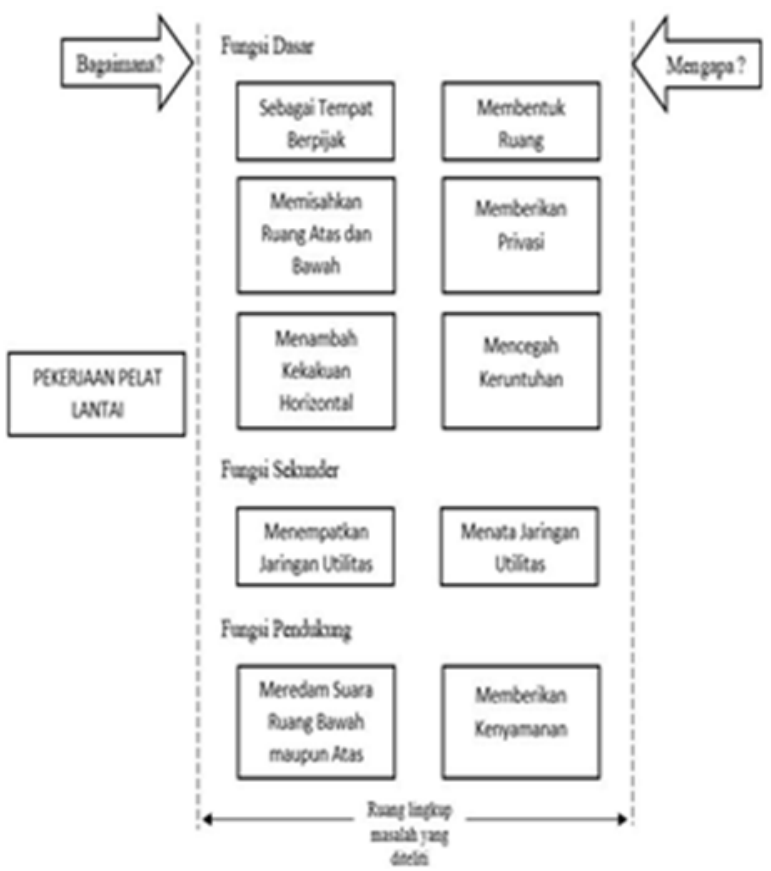

Fig.3. FAST Diagram of floor plate work

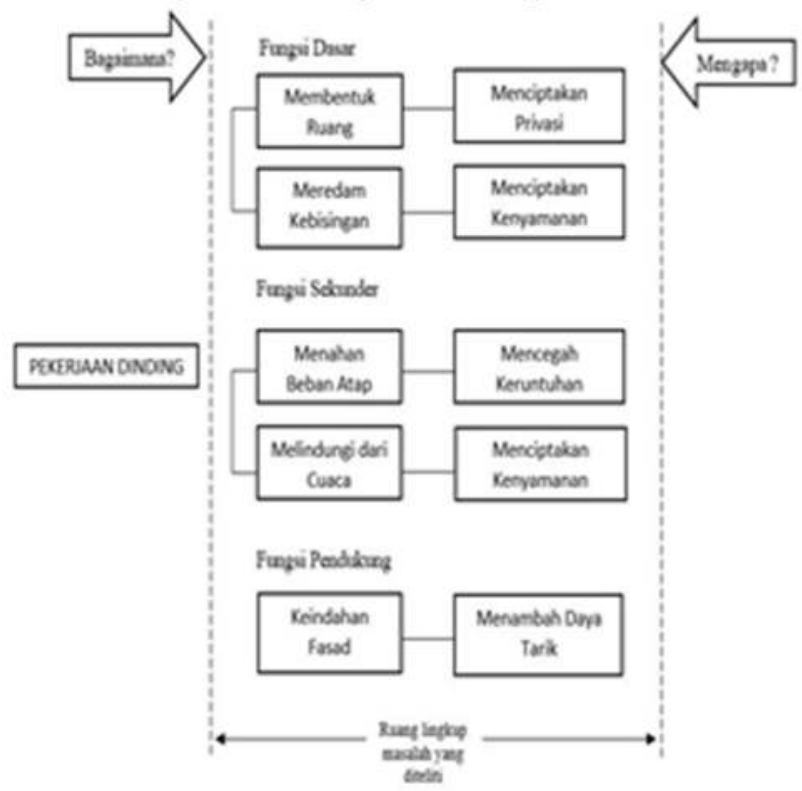

Fig.4. FAST Diagram of wall work

Next, analyzing the function of the reviewed work items. Based on the results of the cost / worth analysis carried out on the roof work, wall work and floor plate work, they have a value 
of cost / worth $>1$, which means that there are unnecessary costs and value engineering can be carried out.

\subsection{Creative Stage}

The creative ideas obtained are:

Table 3. Roof work's alternative

\begin{tabular}{ll}
\hline Project & Movie Theater of Suzuya Plaza \\
Location & Tanjung Morawa \\
Item & Roof \\
Function & To protect the building \\
No. & Alternative Design \\
A0 & Early Design : double plate tin roof (galvalum+insulation+wave tin) \\
A1 & 0,35 mm Zincalum Spandek+ aluminium voil \\
A2 & Galvanized + aluminium voil \\
\hline
\end{tabular}

Table 4. Floor plate work's alternative

\begin{tabular}{ll}
\hline Project & Movie Theater of Suzuya Plaza \\
\hline Location & Tanjung Morawa \\
\hline Item & Floor Plate \\
\hline Function & To separate space and to increase horizontal stiffness \\
\hline No. & Alternative Design \\
\hline A0 & Early Design : readymix reinforced concrete + wiremesh iron \\
A1 & Precast cncrete + wiremesh iron \\
A2 & Reinforced Concrete (manual) + wiremesh iron \\
A3 & Galvanized Bondek Structural Steel Floor Sheets \\
\hline
\end{tabular}

Table 5. Wall work's alternative

\begin{tabular}{ll}
\hline Project & Movie Theater of Suzuya Plaza \\
\hline Location & Tanjung Morawa \\
\hline Item & Wall coating work \\
\hline Function & To beautify the wall \\
\hline No. & Alternative Design \\
\hline A0 & Early Design : Brick Wall ,Stucco + Acian \\
A1 & Partition Wall, Gypsum \\
A2 & Bruck wall,Alumunium Composite Panel (ACP), aluminium hollow frame \\
A3 & Kalsipart Wall 8,metal frame \\
\hline
\end{tabular}

\subsection{Analysis Stage}

After analyzing the alternative 1 advantages and disadvantages, the roof work has the highest total assessment results in terms of initial costs, aesthetics, implementation time, level of implementation, level of durability and comfort, and environmental friendliness.

\subsection{Development Stage}

In the development stage, the cost calculation for alternative 1 is carried out which is Zincalume Roof $0.35 \mathrm{~mm}+$ aluminum with a total cost of Rp. 251,436,416 which means obtained cost savings of Rp. 183,123,584 with an RAB of Rp. 434,560,000. On the wall work, the alternative cost chosen is Rp. 273,715,960 while the initial cost is only Rp. .633,276 which means no savings are obtained. And on the floor plate work, the alternative cost generated which is Rp. 790,692,350 with an initial cost of Rp. 748,429,529 is also did not get savings. 


\subsection{Presentation Stage}

Displaying the results of analysis of the advantages and disadvantages in graphical form. In the results of analysis of the advantages and disadvantages of roof work, an alternative that gets the highest rating compared to other alternatives and with the initial design is the alternative of zincalume roof $0.35 \mathrm{~mm}+$ aluminum voil (Figure 5).

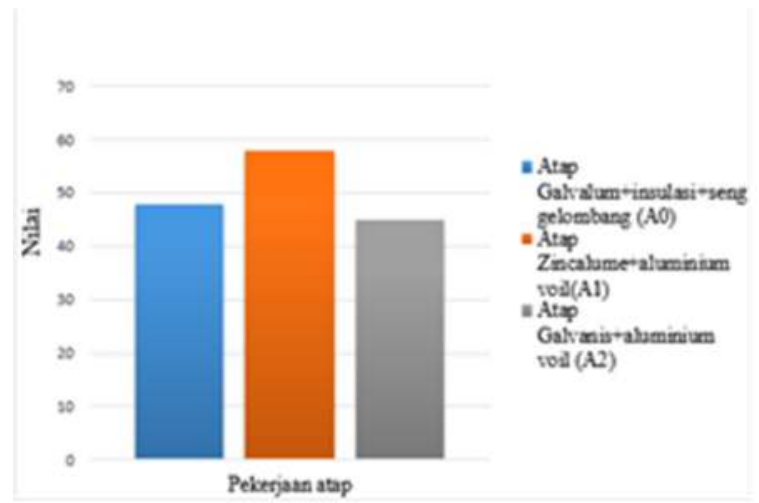

Fig.5. Graph of roof work analysis results

In the analysis of the advantages and disadvantages of floor plate work, the alternative that gets the highest rating compared to other alternatives and with the initial design is the alternative of bondek galvanized structural steel floor sheets (Figure 6).

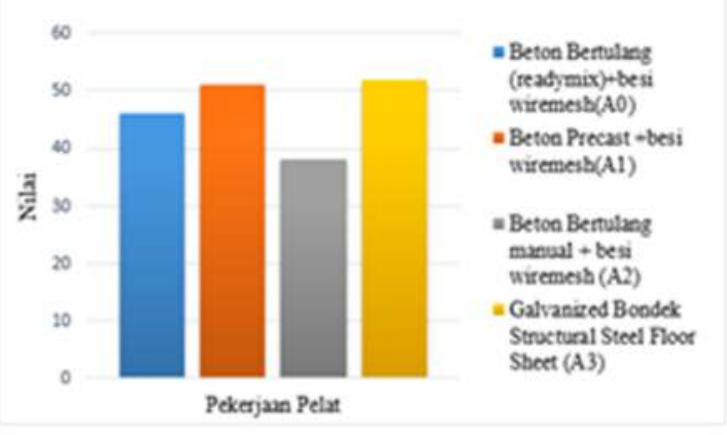

Fig.6. Graph of plate work analysis results

In the results of the analysis of the advantages and disadvantages of wall work, the alternative that gets the highest rating compared to other alternatives and with the initial design is on the alternative of kalsipart wall 8 (Figure 7). 


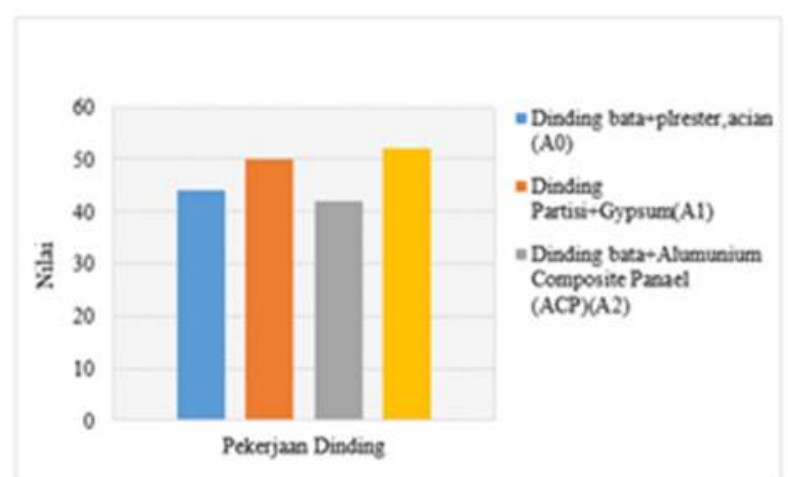

Fig. 7. Graph of wall work's alternative analysis results

\section{Conclusion}

From the results of the value engineering analysis on the construction project of Movie Thaeter of Suzuya Plaza of Tanjung Morawa, it can be concluded that:

First, work components that can be carried out by value engineering analysis are on roof work, beam work, column work, floor plate work, and wall work.

Second, the alternative chosen for each work is an alternative that has the highest value from the results of advantages and disadvantages analysis in terms of initial costs, aesthetics, implementation time, implementation level, durability level, comfort level, and level of environmental friendliness.

Third, the cost of savings obtained on roof work which is the highest cost work item is Rp. 183,123,584 with an RAB of Rp. 434,560,000. The savings obtained is $3.6 \%$ of the initial cost of the analyzed structural work, which is Rp. 5,079,237,828. Whereas in other work items after being analyzed, the cost does not get cost savings so it is not proposed to replace the initial design.

\section{Suggestions}

The implementation of value engineering on construction project of movie theater of Suzuya Plaza of Tanjung Morawa should be carried out in the early stages of the project to get a more optimal savings results.

\section{References}

[1] C. F. Gray and E. W. Larson, Manajemen Proyek Proses Manajerial. Yogyakarta: Andi Offset, 2007.

[2] P. Mahardika, "Penerapan Rekayasa Nilai Pada Proyek Pembangunan Gedung Kuliah Dan Poliklinik Universitas Kristen Petra Surabaya (Studi Pada Item Pekerjaan Arsitektur),” Institut Teknologi Sepuluh Nopember, 2004.

[3] S. Chandra, Maximizing Construction Project and Investment Budget Efficiency with Value Engineering. PT. Elek Media Komputindo, 2014. 
[4] I. Dell, Value Engineering in the Construction Industry. 1974.

[5] L. D. Miles, Techniques of Value Analysis and Engineering. Miles Value Foundation, 2015.

[6] E. D. Heller, Value management: Value Engineering and Cost Reduction. Addison-Wesley Publishing Company, 1971. 